\title{
Influence of feeding different calcium levels in layers diet on the mineral content of the eggs and shells
}

$*^{1}$ Akinola, L. A. F. and ${ }^{1}$ Obene, C. I.

${ }^{1}$ Department of Animal Science, Faculty of Agriculture, University of Port Harcourt, Choba, Port Harcourt, P.M.B. 5323 Port Harcourt, Rivers State, Nigeria

\section{Abstract}

*Corresponding Author: letorn.akinola@uniport.edu.ng; lafakinola@gmail

This study was conducted to determine the influence of feeding calcium levels in layers' diet on the mineral content of the eggs and shells. One hundred and twenty black Harco layers which were 42 weeks old were randomly assigned to four treatment groups designated as $T_{1}$, $T_{2}, T_{3}$ and $T_{4}$ in a completely randomized design. Each treatment consisted of three replicates which had 10 birds each. The set of 10 hens were kept in each demarcation in an open-sided poultry house (deep litter) well-constructed with cages for egg collection. The calcium inclusion levels in the diets were: $T_{1}=2.5 \%, T_{2}=3.5 \%$ (control), $T_{2}=4.5 \%$ and $T_{4}=5.5 \%$. Daily routine practices such as feeding, cleaning, and environmental sanitation were carried out to ensure better results. Hygienic condition and routine management practices were also carried out during the experimental period. At the end of 12 weeks of study six eggs were collected per replicate (18 eggs per treatment) for the study of the mineral content of the egg and the calcium $(\mathrm{Ca})$ and phosphorus $(\mathrm{P})$ concentration of the eggshell. From the result obtained, the egg minerals were significantly $(P<0.05)$ affected by the diets except the phosphorus and sodium ( $\mathrm{Na}$ ) content. Treatment 4 had a significantly higher level of calcium while the lowest was $T_{1}$. Furthermore, $T_{1}$ had the highest level of potassium $(K)$ which was significantly different $(P<0.05)$ from others while the lowest was $T_{4}$. The calcium content of the egg shell was significantly $(P<0.05)$ different amongst the treatment groups with $T_{1}$ having the highest level while $T_{4}$ had the lowest. The phosphorus content of the shell was also significantly $(P<0.05)$ affected across the treatment groups with $T_{1}$ having the highest level of phosphorus and the lowest in $T_{2}$. It was therefore concluded that increasing the level of calcium up to 5.5\% may favor dietary minerals and the nutrition of man who are the end users of egg since Ca plays a vital role in body metabolism.

Keywords: Calcium, Eggs, Eggshell, Laying Hens, Minerals

\section{Introduction}

Calcium $(\mathrm{Ca})$ is an important major cation that is needed in animal diet. It is the most abundant mineral element in the body and is supplemented as ground limestone (CaCO3) because more than $80 \%$ of the $\mathrm{Ca}$ in the earth's crust exists as limestone (Veum, 2010). Calcium is needed for several functions by birds (Nunes et al., 2006), including eggshell formation (Costa et al., 2008). Thus, laying hens require high calcium (Ca) level especially during egg production (Leeson and Summers, 2005). A deficiency of calcium in diet of laying hens had been found to result in decreased egg production according to Leeson and Summers (2005). Although, egg production returns to normal within 6 to 8 days if fed with adequate diet that is rich in calcium. Whitehead (2004) stated that the medullary bone is a woven bone that acts as a liable source of calcium for eggshell formation. Laying hens require $3.5 \% \mathrm{Ca}$ according to NRC (1994) when the feed consumption is 
$100 \mathrm{~g} / \mathrm{bird} /$ day while the calcium requirement by commercial layers is $3.9 \%$ according to Rostagno et al. (2011). Ehtesham and Chowdhury (2002) observed that poultry producers are always interested in high production at minimum expenditure on nutrients so as to economize their feeding practices. According to Silva and Santos (2000), the use of calcium carbonate resulted in higher egg production than dicalcium phosphate. The Supplementation of $50 \%$ limestone with oyster shell was found to increase egg production while marine calcium can replace up to $45 \%$ of calcitic limestone with no effects on performance or egg quality (Ahmad and Balander, 2003). Calcium (Ca) and phosphorus $(\mathrm{P})$ are considered as the main minerals in diets of layers and breeder due to their expressive participation in the metabolism and quality of the egg shell and the metabolic and structural function of these minerals in eggshell formation which are necessary for poultry production (Araujo, 2005).

Studies on the importance of calcium in egg production have been of interest to Nutritionists for a long time. Many studies have focused on the role of calcium on egg production, egg shell thickness, egg weight, and body weight, egg breaking strength, feed intake and feed conversion ratio (Chen and Chen, 2004). It is important that the right quantity of calcium is provided for laying hens. The provision of calcium in the right quantity to layers will serve to ensure that the eggs produced are of the right quality (both in terms of the nutritional value and shell quality). Thus, this study was conducted to examine the influence of feeding different levels of calcium in layers diet on the egg minerals and shell calcium and phosphorus content since most farmers use only commercial feeds which have $3.5 \%$ calcium according to their bag labels.

\section{Materials and methods \\ Experimental location}

This experiment was carried out at the Poultry Unit of University of Port Harcourt Teaching and Research Farm, Choba, Port Harcourt, Rivers State.

\section{Experimental animal, management and design}

One hundred and twenty black Harco birds of 42 weeks old were purchased and were used to carry out this study. The birds were housed in deep litter system in an opensided poultry house that was well demarcated into replicates. The birds were randomly assigned to 4 treatment $\left(\mathrm{T}_{1}-\mathrm{T}_{4}\right)$ groups. Each treatment was replicated thrice with 10 birds per replicate (a total number of 30 birds per treatment). The experimental design used was the completely randomized design.

Routine management practices were carried out during the period of study while hygienic condition was ensured throughout the experimental period. Daily routine practices such as feeding, cleaning and environmental sanitation were carried out to ensure efficient results.

\section{Experimental feed and duration}

The diets were compounded from the ingredients bought from a feed ingredient shop in Port Harcourt such that the calcium levels (contributed from limestone and bone meal) in the treatments were 2.5, 3.5, 4.5 and $5.5 \%$ for $\mathrm{T}_{1}-\mathrm{T}_{4}$ as shown in Table 1 . The experiment lasted for 12 weeks. 
Akinola and Obene

Table 1: Composition of experimental layers' diets

\begin{tabular}{lllll}
\hline Ingredient (\%) & $\begin{array}{l}T_{1} \\
(2.5 \% \mathrm{Ca})\end{array}$ & $\begin{array}{l}T_{2} \\
(3.5 \% \mathrm{Ca})\end{array}$ & $\begin{array}{l}T_{3} \\
(4.5 \% \mathrm{Ca})\end{array}$ & $\begin{array}{l}T_{4} \\
(5.5 \% \mathrm{Ca})\end{array}$ \\
\hline & & & & \\
Maize & 37.25 & 37.25 & 38.25 & 38.25 \\
Palm kernel cake & 15.00 & 15.00 & 15.00 & 15.00 \\
Soya bean meal & 13.00 & 13.00 & 14.00 & 15.00 \\
Groundnut cake & 10.00 & 10.00 & 8.00 & 7.00 \\
Fish meal & 2.00 & 2.00 & 3.00 & 3.00 \\
Wheat bran & 14.00 & 11.00 & 7.50 & 5.00 \\
Palm oil & 2.00 & 2.00 & 2.00 & 2.00 \\
Limestone & 3.50 & 5.00 & 6.50 & 8.00 \\
Bone meal & 2.50 & 4.00 & 5.00 & 6.00 \\
Dl meth & 0.05 & 0.05 & 0.05 & 0.05 \\
Lysine & 0.05 & 0.05 & 0.05 & 0.05 \\
${ }^{1}$ Vit/Min & 0.25 & 0.25 & 0.25 & 0.25 \\
Salt & 0.40 & 0.40 & 0.40 & 0.40 \\
Total & 100.0 & 100.0 & 100.0 & 100.0 \\
\hline Calculated nutrient $(\%)$ & & & & \\
\hline Crude protein & 19.40 & 19.33 & 19.05 & 19.02 \\
ME (Kcal/kg) & 2540.74 & 2508.06 & 2498.84 & 2496.81 \\
Fat & 5.16 & 5.04 & 4.99 & 4.98 \\
Crude fibre & 5.49 & 5.44 & 5.12 & 4.98 \\
Lysine & 0.88 & 0.87 & 0.89 & 0.88 \\
Meth & 0.33 & 0.33 & 0.34 & 0.34 \\
Ca & 2.50 & 3.54 & 4.54 & 5.51 \\
Avail, P & 0.99 & 1.17 & 1.31 & 1.42 \\
Ca: P & $2: 1$ & $3: 1$ & $3.5: 1$ & $4: 1$ \\
\hline
\end{tabular}

${ }^{1}$ Vitamin and Tr ace mineral for each kg contained: Mn 40g, Fe 20g, Zn 18g, Cu 0.8g, I 0.62g, Co 0.09g and Se $0.04 \mathrm{~g}$, pantothenic acid 1,000,000 I.U, cholecalciferol 1,100,000 I.U, quinones $0.8 \mathrm{~g}$, thiamin $0.6 \mathrm{~g}$ and riboflavin $2.4 \mathrm{~g}$, folic acid $0.4 \mathrm{~g}$, biotin $0.02 \mathrm{~g}$, ascorbic acid $10.0 \mathrm{~g}$, Choline chloride $120.0 \mathrm{~g}$, zinc bacitracin $80.0 \mathrm{~g}$, avatec $30.0 \mathrm{~g}$

\section{Data collection and analysis}

At the end of the 12th week, six eggs were collected per replicate making a total of 18 eggs per treatment. The eggs were analyzed to obtain the mineral components of the egg and the calcium and phosphorus content of the egg shells.

The egg yolk and albumen of the individual egg were mixed together and used to determine the mineral content of the egg. The calcium content was obtained by measuring the sample absorbance according to colorimetric method described by Briggs and Moorehead (1974). The magnesium content was obtained using: (Magnesium concentration $(\mathrm{mg} / \mathrm{dL})=$
Absorbance of sample $\div$ absorbance of standard $\times$ standard concentration) according to the method described by Farrel (1984). The sodium content of the egg was obtained using the method of Maruana (1958) and Trinder (1951) while the potassium was obtained using the method of Henry et al. (1974). The Phosphorus content of each of the egg was obtained using: Phosphorus concentration $(\mathrm{mg} / \mathrm{dL})=$ Absorbance of sample $\div$ absorbance of standard $\times 5$ after the incubation at room temperature for 5 minutes and the reading of the absorbance of sample and standard was read against the reagent blank as described by Tietz(1983). 


\section{Effect of calcium in diets on egg and shell minerals}

The eggshell was obtained after removing the albumen and the yolk. The membrane was removed and the shell allowed to airdry. The eggshell was milled to powder using the mortar and pestle. The method described by described by Briggs and Moorehead (1974) was used to obtain the calcium content of the egg shell while the method described by Tietz (1983) was used to obtain the phosphorus content the egg shell.

\section{Results}

The influence of the diets on the egg mineral composition is shown in Table 2 . The diets significantly affected $(p<0.05)$ the magnesium $(\mathrm{Mg})$, potassium $(\mathrm{K})$ and calcium $(\mathrm{Ca})$ contents of the eggs while no effects were noticed in phosphorus (P) and sodium $(\mathrm{Na})$.

The significant $(P<0.05)$ effect observed in magnesium was such that $\mathrm{T}_{1}(2.02 \pm 0.04$ $\mathrm{mg} / \mathrm{dL}$ ) had the highest level which was not different from $\mathrm{T}_{4}$ while $\mathrm{T}_{2}$ and $\mathrm{T}_{3}$ were significantly $(P>0.05)$ smaller. The diets influenced potassium content of the eggs such that $\mathrm{T}_{1}$ had the highest level while the level of $\mathrm{K}$ decreased as the calcium level in the diets increased. The diets also significantly $(P<0.05)$ affected the calcium levels of the eggs such that the highest calcium level was observed in $\mathrm{T}_{4}$. The result showed that the calcium level of the eggs increased as the calcium in the diet increased. There were no significant $(P>0.05)$ differences in the effect of the diets on $\mathrm{P}$ and $\mathrm{Na}$ across the treatment groups.

Table 2: Effect of treatments on the mineral composition of the egg

\begin{tabular}{llllll}
\hline Parameters & $\mathbf{1}$ & $\mathbf{T}_{\mathbf{2}}$ & $\mathbf{T}_{\mathbf{3}}$ & $\mathbf{T}_{\mathbf{4}}$ & SEM \\
\hline Magnesium (mg/dL) & $2.02^{\mathrm{a}}$ & $1.93^{\mathrm{b}}$ & $1.91^{\mathrm{b}}$ & $1.97^{\mathrm{ab}}$ & 0.32 \\
Phosphorus (mg/dL) & 3.92 & $3.51^{\mathrm{b}}$ & 2.50 & 2.87 & 0.39 \\
Potassium (mmol/L) & $2.85^{\mathrm{a}}$ & $2.21^{\mathrm{b}}$ & $1.89^{\mathrm{c}}$ & $1.52^{\mathrm{d}}$ & 0.10 \\
Calcium (mmol/L) & $2.21^{\mathrm{c}}$ & $2.32^{\mathrm{b}}$ & $2.30^{\mathrm{b}}$ & $2.39^{\mathrm{a}}$ & 0.20 \\
Sodium (mmol/L) & 1.45 & 1.49 & 1.45 & 1.42 & 2.44 \\
\hline
\end{tabular}

a,b $=$ means within each row that bear different superscripts differ significantly

The influence of the diets on the calcium and phosphorus content of the egg shell is shown in Table 3 . The diets significantly affected $(P<0.05)$ the $\mathrm{P}$ and $\mathrm{Ca}$ content of the egg shell. The phosphorus content of the egg shell was observed to be significantly higher in $\mathrm{T}_{1}$ and was not different from $\mathrm{T}_{4}$ This was followed by $\mathrm{T}_{3}$ and $\mathrm{T}_{2}$ having 2.72 $\pm 0.17 \mathrm{mg} / \mathrm{dL}$ and $1.78 \pm 0.16 \mathrm{mg} / \mathrm{dL}$, respectively.

The diets also significantly $(P<0.05)$ affected the calcium content of the egg shell such that $\mathrm{T}_{1}$ had the highest level of calcium $2.35 \pm 0.34 \mathrm{mmol} / \mathrm{L}$. The calcium level of the eggshell decreased across the treatments as the level in the diet increased.

Table 3: Effect of dietary treatments on the calcium and phosphorus content of the egg shell

\begin{tabular}{llll}
\hline Treatment & Phosphorus & $(\mathbf{m g} / \mathbf{d L})$ & Calcium $(\mathbf{m g} / \mathbf{d L})$ \\
\hline 1 & $3.30^{\mathrm{a}}$ & $2.35^{\mathrm{a}}$ \\
2 & $1.78^{\mathrm{c}}$ & $2.22^{\mathrm{b}}$ \\
3 & $2.72^{\mathrm{b}}$ & $2.07^{\mathrm{c}}$ \\
4 & $2.95^{\mathrm{ab}}$ & $2.12^{\mathrm{c}}$ \\
SEM & 0.18 & 0.20 \\
\hline
\end{tabular}

$\overline{a, b}=$ means within each column that bear different superscripts differ significantly 


\section{Akinola and Obene}

\section{Discussion}

The significant differences in the magnesium $(\mathrm{Mg})$ content of eggs observed in this study showed that the diets which varied in the $\mathrm{Ca}$ content affected the $\mathrm{Mg}$ content of the eggs. This result was similar to that of Atteh and Leeson (1983) who found that increasing the $\mathrm{Mg}$ and $\mathrm{Ca}$ content of feeds caused a reduction in the percentage of magnesium retained in the egg. However, Leeson and Summers (2001) reported that increasing the levels of $\mathrm{Ca}$ and $\mathrm{P}$ in the diet of laying hens resulted in increased $\mathrm{Mg}$ content of the eggs. It could therefore, imply that $\mathrm{T}_{1}$ and $\mathrm{T}_{4}$ were better diets for this age of hens (42 weeks) since $\mathrm{Mg}$ also plays an important role in egg shell formation (Leeson and Summers, 2001). Maynard et al., (1979) had stated earlier that excess levels of $\mathrm{Ca}$ and $\mathrm{P}$ could interfere with nutrients like $\mathrm{Zn}$ or $\mathrm{Mg}$ resulting in deficiency of these minerals.

The treatments which had no effect on the phosphorus content of the eggs may confirm that the ratio of $\mathrm{Ca}: \mathrm{P}$ was adequate in the diets, since Underwood (1981) stated that excess of one or both of $\mathrm{Ca}$ or $\mathrm{P}$ will lead to the reduction in the availability of the other due to the formation of insoluble $\mathrm{Ca}$ phosphate in the intestine. The nonsignificant difference in the phosphorus content of the eggs also supports Nys et al. (2004) who stated that eggs usually have consistent content of total lipids, phospholipids, phosphorus, iron and essential amino acids. Also, Pastore et al. (2012), had reported that calcium of 3.51\% (similar to the control in this study), met the requirements of calcium of layers up to 42 to 58 weeks of age. A similar report by NRC (1994) specified that the appropriate level of $\mathrm{Ca}$ to be used in the diets should be $3.5 \%$ for laying hens when the feed consumption is $100 \mathrm{~g} / \mathrm{bird}$ per day.

The result of the present study, which showed that increasing the calcium level of the diet up to $5.5 \%$ significantly decreased the potassium content and increased the calcium content of the eggs was in line with the report by Anderson et al. (1995) who reported that the absorption of $\mathrm{Ca}$ is usually higher than any other minerals, causing the availability of other minerals such as potassium, magnesium, phosphorus and sodium to be affected or reduced. The nonsignificant effect of the diets on the sodium content of the eggs across the treatment groups may be due to the adequate $\mathrm{Ca}$ : $\mathrm{P}$ ratio of the diets.

The increment in the calcium level of the diets which had significant effect on the phosphorus content of the eggshell was in line with the report by Anderson et al, (1995), who stated that high calcium intake in laying hens affected phosphorus utilization as a result of the changes in the ratio of $\mathrm{Ca}$ : $\mathrm{P}$. The significantly higher $\mathrm{P}$ content of the eggshell in $\mathrm{T}_{1}(3.30 \mathrm{mmol} / \mathrm{L})$ tallied with the report that a narrow $\mathrm{Ca}$ : total $\mathrm{P}$ ratio of approximately 1:1 (in this case $2: 1$ ) increases the efficiency of $\mathrm{P}$ absorption and increases the bone strength of broiler chicks (Sebastian et al., 1996, Qian et al., 1997) and growing swine (Liu et al., 1998). It also confirmed the report by Veum (2010) that a narrow $\mathrm{Ca}$ : $\mathrm{P}$ ratio increases the efficiency of $\mathrm{P}$ absorption in non-ruminants. Thus, the significant differences in the $\mathrm{P}$ content of the eggshell may be attributed to the variations in the $\mathrm{Ca}$ : $\mathrm{P}$ ratio of the diets since a range of $1: 1$ to $2: 1$ was recommended for broilers, turkeys and swine (NRC, 1994, 1998) while egg-laying poultry was regarded as an exception, where the $\mathrm{Ca}$ : $\mathrm{P}$ ratio may reach $4: 1$ or more to support adequate development of the eggshell. Pelicia et al., (2009) also reported that increment in calcium levels in layers' diet with $4 \% \mathrm{Ca}$ and $0.24 \%$ available $\mathrm{P}$ resulted in a significant increase in the $\mathrm{P}$ 
content of eggshells. More importantly, since $\mathrm{Ca}$ is stored almost entirely as hydroxyapatite crystals of $\mathrm{Ca}$ phosphate $\left(3 \mathrm{Ca}_{3}\left(\mathrm{PO}_{4}\right) \cdot \mathrm{Ca}(\mathrm{OH})_{2}\right)$, its mobilization usually results in concurrent release of $\mathrm{P}$ (Whitehead and Fleming, 2000)

The decrease in the calcium content of the eggshells as the $\mathrm{Ca}$ level in the diets increased was in accordance with the report of Scott et al. (1971) who stated that egg production and eggshell content were significantly reduced when the level of calcium was increased to $5 \%$ of the diet. The lowest level of $\mathrm{Ca}$ inclusion in $\mathrm{T} 1$ which also contained the lowest $\mathrm{P}$ inclusion but resulted to the highest level of $\mathrm{Ca}$ and $\mathrm{P}$ content of the eggshells, tallied with the reports of many researchers who reported that low levels of phosphorus improved shell quality (Hunt and Chancey, 1970; Scott et al, 1976; Garlich, 1979).

\section{Conclusion}

The study revealed that increasing the level of calcium in diet for laying hens favored the calcium content of the egg without adverse effect on the phosphorus and sodium level of the eggs. This implied that the use of calcium in diet of laying hens up to $5.5 \%$ will favor the nutrition of man who is the end users of egg, as calcium pays vital role in human metabolism.

The calcium levels of the eggshell obtained in this study showed that increasing the calcium content of feed does not necessarily lead to improved calcium content of the shell. Thus, the farmer's target for increasing calcium in the layers' diet could only play significant role in elevating the calcium content of the egg (dietary calcium).

\section{References}

Ahmad, H. A. and Balander, R. J. 2003. Alternative feeding regime of calcium source and phosphorus level for better eggshell quality in commercial layers. Journal of Applied Poultry Science. 12:509154.

Anderson, K. E., Harvenstein, G. B. and Brake, J. 1995. Effects of strain and rearing dietary regimens on brown-egg pullet growth and strain, rearing dietary regimens, density, and feed space effects on subsequent laying performance. Poultry Science.74:1079-1092.

Atteh J. O. and Leeson S. 1983. Influence of increasing dietary calcium and magnesium levels on performance, mineral metabolism, and egg mineral content of laying hens. Poultry Science. 62, 1261-1268.

Araujo, J.A. 2005. Niveis de calcio, f sforo disponivel e de fitase na dieta de poedeiras ap s a muda forçada [CDROM]. Anais da 42th Reuniao Anual da Sociedade Brasileira de Zootecnia. Goiânia, Goias. Brasil: Sociedade Brasileira de Zootecnia.

Briggs, H. G. and Moorehead, W.R. 1974. Clinical Chemistry. 20: 1458-1460.

Chen. Y. C. and Chen. M. 2004. Effect of calcium supplement particle size and source on the performance of laying chickens. Poultry Science. 56: 1641-1647.

Costa, F. G. P., Oliveira, C. F. S., Dourado, L. R. B., Neto, R. C. L., Campos, M.A.S.F. a n d Lima, A. G. V. O. 2008. Níveis de cálcio em dietas para poedeiras semipesadas após o pico de postura. Revista Brasileira de Zootecnia.37(4):624-628.

Ehtesham, A. and Chowdhury, S. D. 2002. Response of laying hens to diets formulated by following different feeding standards. 
Pakistan Journal of Nutrition1: 127-131.

Farrel, E. C. 1984. Magnesium in Kaplan, A.J Pesce (Eds). Clinical Chemistry. The CV Mosby Co. St. Louis Torento, Princeton. pp 10641069.

Garlich, J. D. 1979. The phosphorus requirement of laying hens. Georgia Nutrition Conference. pp.104- 114

Henry, R. F. Donald, C. C. and James, W. W. 1974. Clinical Chemistry, Principles and Techniques $2^{\text {nd }} \mathrm{Ed}$. Haeper and Row, Hagerstown, M.D.

Hunt, J. R. and Chancey, H. W. R. 1970. Influence of dietary phosphorus on shell quality. British Poultry Science. 11:259-267.

Leeson, S. and Summers, J. D. 2001 Nutrition of the Chicken, 4th edn. University Books, Guelph, Ontario, Canada

Leeson, S. and Summers, J. D. 2005. Commercial Poultry Nutrition 3rd Edition. University Books Guelph, Ontario, Canada.

Liu, J., Bollinger, D. W., Ledouz, D. R. and Veum, T. L. 1998. Lowering the dietary calcium to phosphorus ratio increases phosphorus utilization in low-phosphorus corn-soybeanmeal d i e t s supplemented with microbial phytase for growing-finishing pigs. Journal of Animal Science. 76: 808-813

Maruana, R. F. L. 1958. Clinical Chemistry. Acta. 2:581.

Maynard, L., Loosli, J., Hintz, H., Warner, R. and Zappa, C. R. 1979. Animal Nutrition. $7^{\text {th }}$ ed. McGraw-Hill, New York.

National Research Council, NRC. 1994.
Nutrient Requirements of Poultry, 9th revised edn. National Academy Press, Washington, DC, USA.

National Research Council, NRC. 1998. Nutrient Requirements of Swine, 10 th revised edn. National Academy Press, Washington, DC, USA.

Nunes, R. V., Pozza, P. C., Scherer, C., Campestrini, E., Rocha, L. D., Nunes, C. G. V. and Costa, F. G. P. 2006. Efeito dos teores de cálcio para poedeiras semipesadas durantea fase de prépostura e no início da postura. Revista Brasileira de Zootecnia .35: (5)

Nys, Y., Gautron, J., Garcia-Ruiz, J. M. and Hincke, M. T. 2004. Avian eggshell mineralization biochemical and functional characterization of matrix proteins. Comptes Rendus Palevol. 3:549562.

Pastore, S. M., Gomes, P. C., Rostagno, H. S., Fermando, L., Albino, T., Calderano A. A., Vellasco, C. R., Viana, G. S. and Almeida, R. L. 2012. Calcium levels and calcium: available phosphorus ratio in diets for white egg layers from 42-58 weeks of age. Revista Brasileira de Zoootecnia. 41(12): 2424-1432

Pelicia, K.., Garcia, E. A., Faitarone, A. B. G., Silva, A. P., Berto, D. A., Molino A. B. and Vercese, F. 2009. Calcium and Available Phosphorus Levels for Laying Hensin Second Production Cycle. Brazilian Journal of Poultry Science.11:39-49

Qian, H., Kornegay, E. T. and Denbow, D. M. 1997. Utilization of phytate phosphorus and c a $1 \mathrm{c}$ i u $\mathrm{m}$ a s influenced by microbial phytase, 


\section{Effect of calcium in diets on egg and shell minerals}

cholecalciferol, and the calcium: total phosphorus ratio in broiler diets. Poultry Science. 76: 37-46.

Rostagno, H. S., Albino, L. F. T., Donzele, J. L., Gomes, P. C., Ferreira, A. S., Lopes, D. C. and Oliveira, R. F. M. 2011. Tabelas brasileiras para aves e suínos: composição de alimentos e exigências nutricionais. $3^{\mathrm{a}}$ ed. Viçosa: Universidade Federal de Viçosa.

Scott, M. L., Hull, S. J. and Mullenhoff, P.

A. 1971. The calcium requirements of laying hens and effects of dietary oyster shell upon egg shell quality. Poultry Science. 50, 1055-1063.

Scott, M. L., Antillon, A. and Krook, L. 1976. Effects of calcium phosphorus interrelationships upon eggshell quality. Proceeding of Cornell Nutrition Conference. pp $122-126$

Sebastian S., Touchburn, S.P., Chavez, E.R. and Lague, P.C. 1996. Efficacy of supplemental microbial phytase at different dietary calcium levels on growth performance and mineral utilization of broiler chicks. Poultry Science. 75:
1516-1523.

Silva, J. H. V and Santos, V. J. 2000. Effect of calcium carbonate on the egg shell quality during the forced molt. Revista. Brasileira. Zootecnia. 29(5):1440-1445

Tietz, N. 1983. Clinical Guide to Laboratory Tests. W.B. Saunders Company, Philad,pp. 384.

Trinder, P. 1951. Analyst. 76:596.

Underwood, E. J. 1981. The Mineral Nutrition of Livestock. $C A B$ International, Walling-foed UK.

Veum, T. L. 2010. Phosphorus and Calcium Nutrition and Metabolism: In: Phosphorus and Calcium Utilization and Requirements in Farm Animals, Vitti, D.M.S.S. and Kebreab, E. eds. MPG Books Group, UK. pp. 94-111.

Whitehead, C. C. 2004. Overview of bone biology in the egg laying hen. Poultry Science. 83:193-199.

Whitehead, C. C. and Fleming, R. H. 2000. Osteoporosis in cage layers. Poultry Science. 79: 1033-1041.

Received: $11^{\text {th }}$ November, 2017

Accepted: $20^{\text {th }}$ February, 2018 